\title{
The Determination of the Net Utilization of Proteins by a Shortened Method
}

\author{
By D. S. MILLER AND A. E. BENDER* \\ The Crookes Laboratories Ltd, Park Royal, London, N.W. Iо \\ (Received 18 May 1955)
}

'The various methods of measuring the nutritive value of proteins have been frequently reviewed (Chick, I942; Mitchell, I944; Allison, I949). One of the more valuable of these is the measurement of the biological value by the balance-sheet procedure of 'Thomas (I909) and Mitchell (I923-4), although a considerable drawback to its use is the time and labour required. For example, with the technique described by Henry, Kon \& Watson (I937) the examination of three proteins with twelve rats extends over 7 weeks and involves 120 nitrogen estimations on urine and faeces.

A method is described here, whereby seven proteins can be tested simultaneously in Io days, using thirty-two rats and involving no $\mathrm{N}$ estimations other than on the food. The method is based on the formula already discussed (Bender \& Miller, I953a). In principle the values obtained are the same as those obtained by the Thomas-Mitchell procedure, being a measure of that proportion of the food $\mathrm{N}$ eaten retained by the test animals.

\section{EXPERIMENTAL}

Animals. Rats of our hooded strain were used in all the experiments. The animals were weaned at $2 \mathrm{I}$ days at a weight of about $35 \mathrm{~g}$, and fed for I week on stock diet so that they weighed 50-60 $\mathrm{g}$ at the beginning of the experiment.

Chemical analyses. Body water was determined after killing the rats with chloroform. Incisions were made into the skull, thoracic and body cavities, and the carcasses were dried to a constant weight at $105^{\circ}\left(4^{8} \mathrm{~h}\right)$. Intestinal contents were included.

$\mathrm{N}$ was determined by the Kjeldahl method. Small rats, of less than $\mathrm{I} 5 \mathrm{~g}$ dry weight, were completely digested with $10 \mathrm{ml}$. conc. $\mathrm{H}_{2} \mathrm{SO}_{4} / \mathrm{g}$ dry matter and $20 \mathrm{~g}$ catalyst ( $2 \mathrm{~g} \mathrm{SeO}_{2}, 2 \mathrm{~g} \mathrm{CuSO}_{4} \cdot{ }_{5} \mathrm{H}_{2} \mathrm{O}, 16 \mathrm{~g} \mathrm{~K}_{2} \mathrm{SO}_{4}$ ). The dried carcasses of the larger rats were pounded in a mortar and ro- $15 \mathrm{~g}$ portions digested. 'The large size of the portions compensated for any lack of homogeneity as shown by the agreement between duplicate digestions. Samples of this size, especially those rich in fat, frequently froth violently during digestion, but this frothing was avoided by maintaining the digestion mixture at $120^{\circ}$ for $2 \mathrm{~h}$ before strong heating. The digested material was finally diluted for the micro-estimation of ammonia (Markham, 1942).

Diets. The basal non-protein diet was composed of $15 \%$ margarine fat, $10 \%$ potato starch, I $5 \%$ glucose, $5 \%$ vitaminized carbohydrate mixture (see p. 383 ), $5 \%$ salt mixture (Hawk, Oser \& Summerson, 1947) and 50\% rice starch. The protein

* Present address: Research Department, Bovril Ltd, I $_{4} 8$ Old Street, London, E.C. I. 
under test was substituted for rice starch in the required amount to give $10 \%$ protein $(\mathrm{N} \times 6.25)$. The vitaminized carbohydrate mixture contained $0.06 \mathrm{~g}$ thiamine hydrochloride, $0.2 \mathrm{~g}$ riboflavin, $0.04 \mathrm{~g}$ pyridoxin hydrochloride, $\mathrm{I} \cdot 2 \mathrm{~g}$ calcium pantothenate, $4.0 \mathrm{~g}$ nicotinic acid, $4.0 \mathrm{~g}$ inositol, $\mathrm{2} 2.0 \mathrm{~g} p$-aminobenzoic acid, $0.04 \mathrm{~g}$ biotin, $0.04 \mathrm{~g}$ folic acid, $0.00 \mathrm{I} g$ cyanocobalamin and $12.0 \mathrm{~g}$ choline chloride, made up to $\mathrm{I} \mathrm{kg}$ with maize starch. An oil (40 mg) containing 800 i.u. vitamin A, 60 i.u. vitamin D and $2.5 \mathrm{mg}$ 2-methyl-I:4-naphthoquinone/g was given daily and $\mathrm{I} g$ wheat germ (0.26\% a-tocopherol) weekly.

Grouping of animals. Four litters of eight rats were divided into eight groups of four in such a way that each group contained one rat from each litter, and totalled the same weight within I-2 g. (When unusually large or small rats were present these were discarded and fewer than eight balanced groups used.) Each group contained two bucks and two does, to allow for differences in sex responses though, in fact, no sex difference has been observed. With ten-rat litters, ten groups of test animals may be arranged.

Procedure. One of the groups was fed on the non-protein diet and each of the remaining groups on separate test-protein diets for Io days. At the end of the period the uneaten food was dried at $105^{\circ}$ and weighed, and the food consumed, and hence the $\mathrm{N}$ intake, calculated. The animals were killed with chloroform, and body water was determined.

Calculation. The $\mathrm{N}$ content of the bodies was calculated from the water content. In the preliminary communication of some of these results (Bender \& Miller, $1953 b$ ) the figures were limited to the age range $33^{-57}$ days. Over this range there is a high correlation between the ratio of body $\mathrm{N}$ to body water and age, and the relation approximates closely to a straight line given by the equation

$$
\mathrm{y}=2.92+0.02 x, \text { where } y=\frac{\mathrm{N} \text { (in grams) }}{\mathrm{H}_{2} \mathrm{O} \text { (in grams) }} \times 100 \text { and } x=\text { age in days. }
$$

However, examination of additional results bringing the total number of rats up to 197 and covering the age range of $0-503$ days shows the relation between age and $\mathrm{N} / \mathrm{H}_{2} \mathrm{O} \%$ to be curvilinear, suggesting an exponential form. An equation of this type fitted to the whole data is:

$$
\begin{aligned}
y & =4.83\left(\mathrm{I}-\mathrm{IO}^{-0.0115(x+22.15)}\right) \\
& =4.83-\operatorname{antilog} 10\left(0.4304-0.0 \mathrm{I} \mathrm{I}^{x}\right) .
\end{aligned}
$$

It will be observed that the value $x$ when $y$ is zero is $-22 \cdot 15$ days, and it is of interest that it approximates to the time of conception, stated by Farris \& Griffith ( 1949 ) to be between 22 days $10 \frac{1}{2} h$ and 22 days $21 \mathrm{~h}$ before parturition.

When the values are expressed linearly in this form it is found that the statistical criteria of linearity are only satisfied up to approximately ıoo days of age, the equation becoming

$$
\log (4.8-y)=0.437-0.0123 x
$$

This equation was therefore used throughout. 
The net protein utilization (N.P.U.) was calculated by applying the equation (Bender \& Miller 1953a)

$$
\text { N.P.U. }=\frac{B-\left(B_{k}-I_{k}\right)}{I}
$$

where $B$ and $B_{k}$ are the total body $\mathrm{N}$ of the animals on the test and non-protein diets respectively, and $I$ and $I_{k}$ are the intake of $\mathrm{N}$ in the two groups.

\section{RESULTS}

The N.P.U., expressed as percentages, of some common proteins determined by the method described are given in Table $I$.

Table I. The net protein utilization of some proteins

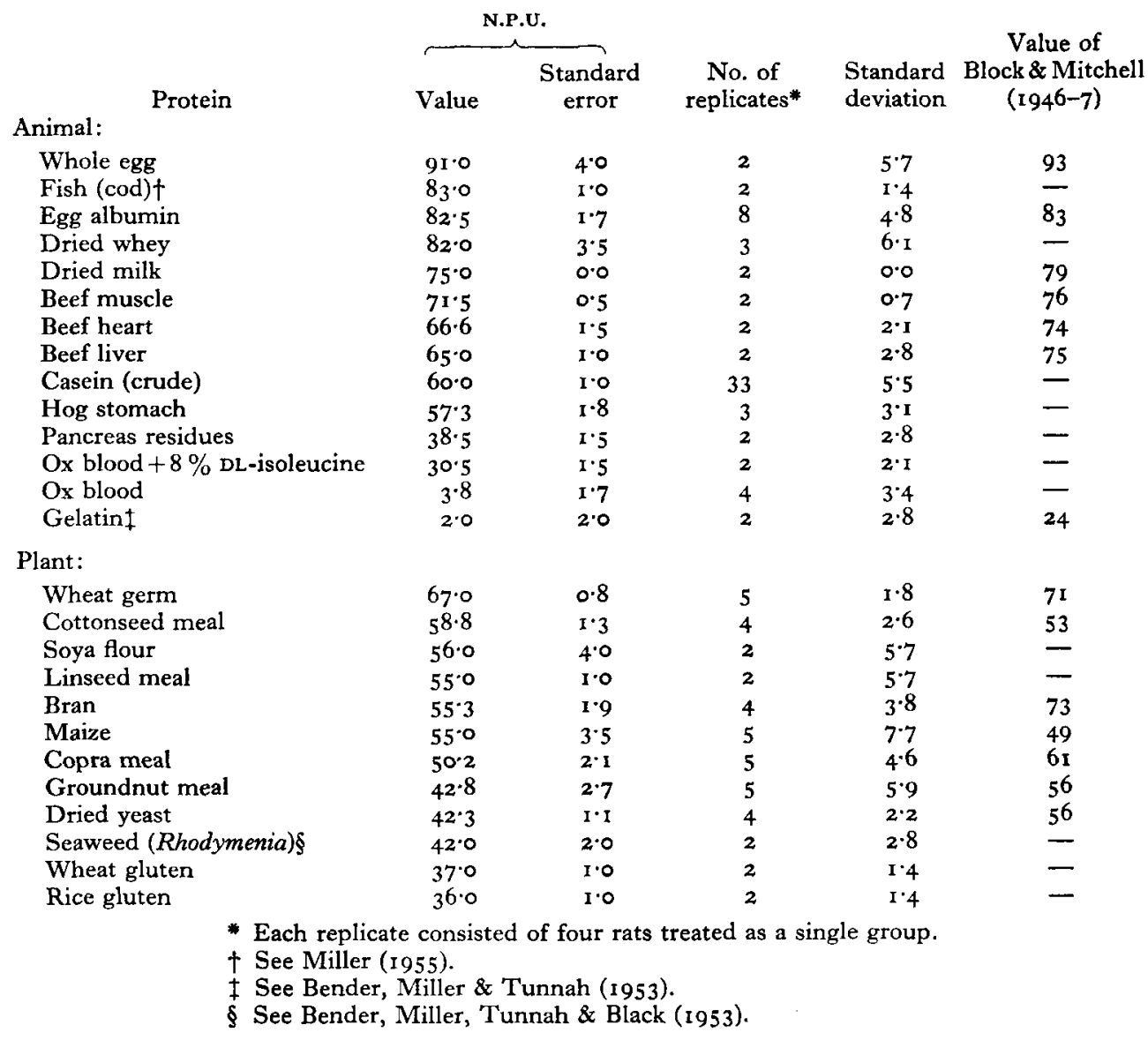

\section{Accuracy of the method}

Although there is no standard series of proteins of precisely known biological value, the results given show good agreement with those reported by other workers using accepted methods and similar material (see review by Block \& Mitchell, 1946-7). In addition, a statistical evaluation of the results may be made by examination of the 
standard deviations of the determinations made. These show that the reliability of the method is of the same order as of that of Mitchell, Burroughs \& Beadles (1936) using classical methods. These authors showed a range of standard deviations on thirty different materials from $1 \cdot 7$ to $7 \cdot 2$ with a mean of $3 \cdot 7$. The results presented here show a range from o to $7 \cdot 7$ with a mean of $3 \cdot 3$ for twenty-six different materials.

\section{Possible sources of error}

Intestinal contents. The error introduced by including the intestinal contents in the analytical measurements of the body was shown by experiment to be insignificant. The intestinal contents of each of a group of rats given $10 \%$ casein and of the nonprotein group were removed and their $\mathrm{N}$ content and that of the carcass determined separately. The results are shown in Table 2.

Table 2. Significance of intestinal contents in the calculation of N.P.U.

$\quad$ Nitrogen in
Carcass excluding intestinal contents (mg)
Intestinal contents (mg)
Food consumed in ro-day period (mg)

\begin{tabular}{|c|c|}
\hline \multicolumn{2}{|c|}{ Diet } \\
\hline $10 \%$ casein & Non-protein \\
\hline $\begin{array}{r}8210 \\
100\end{array}$ & $\begin{array}{r}4614 \\
83\end{array}$ \\
\hline 6834 & $3 \mathrm{I}$ \\
\hline
\end{tabular}

From these the N.P.U. may be calculated in different ways:

(I) Intestinal contents included with carcass, N.P.U. $=57 \cdot 2$;

(2) Intestinal contents excluded completely, N.P.U. $=56 \cdot 4$;

(3) Half the intestinal content treated as unabsorbed food and half as faeces, N.P.U. $=56 \cdot 3$.

The differences between these results are well within the usual variation between replicate determinations.

Calculation of body $N$ from water content. All the values quoted were determined from the equation connecting the $\mathrm{N}: \mathrm{H}_{2} \mathrm{O}$ ratio with age, but the figures in Table 3 show that there is no significant difference between the determinations made using actual body $\mathrm{N}$ analyses and those from calculated figures. The differences between

Table 3. Comparison of values for N.P.U. obtained by analysis and by calculation from $\mathrm{N}: \mathrm{H}_{2} \mathrm{O}$ ratio

\begin{tabular}{|c|c|c|c|c|c|c|}
\hline & & By analysis & & & calculation & \\
\hline & & & & & & \\
\hline Protein & Value & $\begin{array}{l}\text { Standard } \\
\text { error }\end{array}$ & $\begin{array}{l}\text { No. of } \\
\text { replicates }\end{array}$ & Value & $\begin{array}{l}\text { Standard } \\
\text { error }\end{array}$ & $\begin{array}{l}\text { No. of } \\
\text { replicates }\end{array}$ \\
\hline Casein & $58 \cdot 9$ & 0.7 & 4 & $60 \cdot 0$ & $I \cdot O$ & 33 \\
\hline Egg albumin & 82 & & I & $82 \cdot 5$ & $\mathrm{I} \cdot 7$ & 8 \\
\hline Dogfish meal & 48 & & I & $52 \cdot 5$ & $1 \cdot 5$ & 2 \\
\hline Dried whey & 86 & & $\mathbf{I}$ & $82 \cdot 0$ & $3 \cdot 5$ & 3 \\
\hline Bran & 57 & & $\mathbf{I}$ & $55^{\circ} 3$ & $1 \cdot 9$ & 4 \\
\hline Protein $M^{*}$ & $5^{6 \cdot 6}$ & $2 \cdot 2$ & 3 & $5^{8 \cdot 6}$ & $2 \cdot 3$ & 3 \\
\hline
\end{tabular}


the $\mathrm{N}: \mathrm{H}_{2} \mathrm{O}$ ratio at 40 days of different colonies is small (Bender \& Miller, I955), and it may be that little error would be involved by applying a mean equation for the different colonies examined to all rats including colonies for which no previous information had been obtained. However, it would seem preferable to determine the $\mathrm{N}: \mathrm{H}_{2} \mathrm{O}$ ratio for any such colony at the age at which a proposed assay is scheduled to be completed.

Grouping of rats. As the method depends upon the difference between the body $\mathrm{N}$ of rats receiving protein and non-protein diets it is important that the two groups should begin the experiment as alike as possible. The usual procedure is to arrange the groups so that the total weight differs by not more than $2 \mathrm{~g}$, but in an experiment in which the groups were not balanced so carefully, the error introduced was not large. Thus protein extracted from pancreas residues tested with group weights differing by $2 \mathrm{~g}$ (test group $276 \mathrm{~g}$, non-protein group $274 \mathrm{~g}$ ) gave a N.P.U. of 40 , compared with the value of 36 obtained when group weights differed by $19 \mathrm{~g}$ (test group $259 \mathrm{~g}$, non-protein group $240 \mathrm{~g}$ ).

Sex differences. In most of the experiments described here the groups of rats were chosen to include two bucks and two does, but no difference has been found between the sexes. Thus casein measured with males gave a value of $66 \cdot 5$ and with females $67 \cdot 2$.

\section{Modified procedures}

A number of modifications to the method described above have been tried in special instances.

Biological value. It is occasionally of importance to distinguish between the $\mathrm{N}$ losses from a food due to poor digestibility and those due to poor biological value. As net protein utilization is the product of biological value and digestibility, it is necessary to measure only the faecal $\mathrm{N}$ of the test and non-protein groups and thereby calculate digestibility in order to derive both values:

$$
\text { Digestibility }(D)=\frac{I-\left(F-F_{k}\right)}{I},
$$

where $F$ and $F_{k}$ are the faecal $\mathrm{N}$ values on the protein and non-protein diets respectively, and $I$ is the intake of nitrogen on the protein diet.

$$
\text { Biological value }=\frac{\text { N.P.U. }}{D}
$$

Alternative controls. Mitchell \& Carman (1926) introduced the procedure of feeding a low level of completely assimilable protein in place of the non-protein diet of the classical procedure, thereby avoiding any physiological changes due to the deprivation. In the present experiments this procedure has been found valuable in prolonged feeding tests where small rats could not withstand long periods on a non-protein diet. The calculation is in no way affected. The expression $I_{k}$ takes into account the $\mathrm{N}$ intake on for example a $4 \%$ egg diet, and the only assumption is that this has a N.P.U. of $100 \%$.

In a similar way the control group can receive a standard protein of known N.P.U. 'This method is of value in the measurement of poor proteins, because of the error 
involved in subtracting two small numbers $\left(B-B_{k}\right)$ each with a possible experimental error. The value of the test protein by this method is given by

$$
\text { N.P.U. }=\frac{B-\left(B_{p}-I_{p} \times \text { N.P.U.p.p }\right)}{I},
$$

where $B_{p}, I_{p}$ and N.P.U. $p$ are respectively the body $\mathrm{N}$ and the intake $\mathrm{N}$ of the group fed the control protein which has a net protein utilization of N.P.U. $p$.

Limiting amino-acid. The brevity of the method facilitates the estimation of the limiting amino-acid in a given protein. By supplementing the protein with triads of the nine amino-acids essential for the rat as is shown in Table 4 it is possible to achieve this information in one assay (i.e. seven determinations). In the example quoted it will be seen that the greatest response is in the second row and first column, indicating methionine to be the limiting amino-acid in casein; subsequent supplementations have confirmed this. An approximation of the extent of the limitation may be reached by feeding the limiting amino-acid at various levels. Thus casein supplemented with $1 \cdot 2,2 \cdot 5,3^{\cdot 2}$ and $4 \cdot 4 \%$ methionine gave values of $71,76,79$ and 78 respectively, indicating a maximum response at the $2 \cdot 5 \%$ level.

Table 4. The N.P.U. of casein supplemented with triads of amino-acids

\begin{tabular}{lccc} 
& \multicolumn{4}{c}{ (Casein alone, N.P.U. $=60 \cdot 0 \pm \mathrm{r} \cdot 0$ ) } \\
Histidine & Lysine & Tryptophan & $6 \mathbf{r}$ \\
Methionine & Threonine & Leucine & 84 \\
Valine & Isoleucine & Phenylalanine & 60 \\
80 & 60 & $6 \mathbf{r}$ &
\end{tabular}

Seven-day experiment. Since this work was completed one of us (A.E.B.) has shown that a 7 -day experimental period gives the same results as the ro-day period.

\section{DISCUSSION}

The advantage of the method described here over the classical procedure is the small number of measurements to be made and the concomitant brevity of the experimental period. Thus the evaluation of three proteins by the Mitchell method with twelve rats involves a total of $120 \mathrm{~N}$ estimations on urine and faeces as well as three food analyses and sixty measurements of food consumption over a period of 7 weeks. The present method evaluates seven proteins with thirty-two rats and requires thirty-two dryweight estimations and eight food-consumption measurements over a period of ro days. In practice it is possible to carry out a group of tests every week, so that with the overlap, seven results are obtained weekly.

Because of the brevity of the experimental period, little change in the physiological condition of the rats would be expected, and in any event it is automatically compensated for by the control group. In the Mitchell method, considerable changes in $\mathrm{N}$ excretion occur over the time of the experiment, although the initial and final endogenous measurements are intended to allow for them. 
The disadvantage of the method is that by grouping four rats on test, a single figure is obtained for the answer with no estimate of variance. It may be overcome by carrying out replicate estimations with two or more groups of four rats.

\section{SUMMARY}

I. A rapid method of estimating the net protein utilization (N.P.U.) of proteins is described which takes only to days. Groups of four rats are given the test diets for this period and a similar group is given a non-protein diet. The N.P.U. is calculated from the formula

body $\mathrm{N}$ of test group - body $\mathrm{N}$ of non-protein group +

$$
\text { N.P.U. }=\frac{\mathrm{N} \text { consumed by non-protein group }}{\mathrm{N} \text { consumed by test group }} .
$$

2. Body nitrogen need not be measured but can be calculated from the water content of the animal as the ratio of $\mathrm{N}$ to water is constant at any given age.

3. The N.P.U. values of twenty-six proteins have been determined and the results indicate the validity of the method as shown by the good agreement with values reported in the literature.

4. When required the biological value can be calculated from the N.P.U. by dividing by the digestibility.

5. A method of determining the limiting amino-acid in the protein is described.

We wish to thank the Directors of the Crookes Laboratories Ltd for permission to publish this work.

\section{REFERENCES}

Allison, J. B. (1949). Advanc. Protein Chem. 5, 155.

Bender, A. E. \& Miller, D. S. (1953a). Biochem. F. 53, vii.

Bender, A. E. \& Miller, D. S. (1953b). Biochem. F. 53, vii.

Bender, A. E. \& Miller, D. S. (1955). In preparation.

Bender, A. E., Miller, D. S. \& Tunnah, E. J. (1953). Chem. E Ind. p. 799.

Bender, A. E., Miller, D. S., Tunnah, E. J. \& Black, W. A. P. (1953). Chem. \&o Ind. p. 1340.

Block, R. J. \& Mitchell, H. H. (1946-7). Nutr. Abstr. Rev. 16, 249.

Chick, H. (1942). Lancet, 242, 405.

Farris, E. J. \& Griffith, J. Q. Jr. (1949). The Rat in Laboratory Investigation, and ed., page facing Pl. 2. Philadelphia: J. B. Lippincott Co.

Hawk, P. B., Oser, B. L. \& Summerson, W. H. (1947). Practical Physiological Chemistry, 12 th ed. p. 1273. London: J. and A. Churchill.

Henry, K. M., Kon, S. K. \& Watson, M. B., (1937). Milk and Nutrition, Part I, p. 37. Reading: National Institute for Research in Dairying.

Markham, R. (1942). Biochem. Y. 36, 790.

Miller, D. S. (1955). F. Sci. Fd Agric. (In the Press.)

Mitchell, H. H. (1923-4). F. biol. Chem. 58, 873 .

Mitchell, H. H. (1944). Industr. Engng Chem. (Anal.), 16, 696.

Mitchell, H. H., Burroughs, W. \& Beadles, J. R. (I 936). F. Nutr. I1, 257.

Mitchell, H. H. \& Carman, G. G. (I 926). F. biol. Chem. 68, 183.

Thomas, K. (1909). Arch. Anat. Physiol., Lpz., Physiol. Abt. p. 2 I 9. 